\title{
SOCIAL CAPITAL AND MUTUAL VERSUS PUBLIC BENEFIT: THE CASE OF RENEWABLE ENERGY COOPERATIVES
}

\author{
by \\ Thomas BAUWENS* \\ University of Liege, Belgium and Ecole Polytechnique Fédérale \\ de Lausanne, Switzerland \\ and \\ Jacques DEFOURNY \\ University of Liege, Belgium
}

\begin{abstract}
One potential major role of social economy organizations in sustainability transitions is the creation and mobilization of social capital. Yet, the social economy gathers very distinct organizational models which may be associated with different types and levels of social capital. Accordingly, the objective of this article is to explore whether, and if so how, the type and level of social capital differ between mutual benefit organizations - which essentially seek to meet their members' needs - and public benefit organizations - which seek to enhance the well-being of a broader community or the society as a whole. The study draws on an econometric analysis of different forms of social capital in two renewable energy cooperatives which are located in Flanders but have clearly divergent orientations toward mutual versus public benefit. The results show that, as compared with an orientation toward public benefit, an orientation toward mutual benefit is associated with lower social identification with the cooperative and weaker ties between members. Our study explores the underlying explanatory mechanisms behind these relationships. Its findings contribute to understanding the potential roles played by cooperatives in sustainability transitions.
\end{abstract}

Keywords: Social capital, community, sustainability transition, social economy, renewable energy cooperative

JEL classification: L31, P13, Q42

The authors are grateful to Marthe Nyssens, two anonymous referees and the editors of the present special issue for valuable comments and suggestions. They also thank Isabelle Peere for her linguistic revision of the present text. E-mail: Thomas.Bauwens@epfl.ch 
Sustainability transition scholars have often stressed the crucial role that grassroots actors, including organizations belonging to the 'social economy', may play in this process as important vehicles for socio-economic innovations (e.g. Seyfang and Smith 2007; Smith 2012; Seyfang and Haxeltine 2012). While the concept of sustainability transition gained interest only a few years ago, the social economy is a relatively old movement since it can be traced back to the 19th century. It gathers organizations with diverse legal forms - non-profits, cooperatives, mutual societies, charities and other not-for-profit forms depending on legal environments - which seek to integrate concerns other than mere profit maximization and are often characterized by democratic and participatory governance structure (Defourny and Develtere 2000). Arguably, one of the major potential contributions of social economy (SE) organizations to sustainability transitions consists in creating and/or mobilizing social capital, given the important roles personal interactions and social networks typically play in their business models. Despite a lack of consensual and established definition, most scholars accord to define the concept of social capital on a generic level in terms of trust, cooperation and civic-minded behavior (Coleman 1990; Putnam 1993; Fukuyama 1995). A strengthened social capital is considered by an increasing number of scholars to be an essential contribution to foster communities' potential of building sustainability locally and enhancing possibilities to deal with collective action and societal challenges: if people trust each other, they are more likely to sustain mutually productive social exchanges, even if these come at a cost for participants taken individually (e.g. Bowles and Gintis 2002; Ostrom 2003). Indeed, social capital has been shown to be empirically linked to various collective outcomes, some of which are directly relevant to sustainability transitions, such as climate change adaptation (Adger 2003), associational and community volunteerism (Stürmer and Kampmeier 2003; Prouteau and Wolff 2004), democracy and governance (Brehm and Rahn 1997; Rothstein 2001; Rothstein and Eek 2009), natural resource management (Ostrom 1994), economic development (Knack and Keefer 1997; Narayan and Cassidy 2001) and health (Kawachi et al. 1997).

Yet, the social economy gathers very different organizational models, which, though often overlooked by the transition literature, may be associated with distinct types and levels of social capital. In particular, the distinction between 'public benefit' and 'mutual benefit' organizations appears to be relevant in this respect (Somerville and McElwee 2011; Lang and Roessl 2011a; Hatak et al. 2016). Historically, public benefit has been associated with non-profit organizations and most charities, and mutual benefit with the whole range of cooperative and mutual organizations (Gui 1991; Ben-Ner and Gui 2000). In recent years, however, cooperatives have mushroomed in fields where historically they had not been widespread (e.g. health and care, services to disadvantaged people, etc.) and in emerging fields or subfields, such as fair trade (Huybrechts 2007), renewable energy (Huybrechts and Mertens 2014; Bauwens et al. 2016) or microfinance and ethical banking (Bauwens 2010; Périlleux et al. 2011). These 'new' cooperatives or cooperative-like organizations distinguish themselves from the traditional ones, notably by their stronger orientation towards general interest goals rather than the mere satisfaction of member needs (Borzaga and Santuari 2001; Borzaga and Spear 2004). In this perspective, these new models represent hybrids between traditional cooperatives and non-profit organizations, combining key features of both legal forms (Defourny 2001; 
Spear and Bidet 2005; Hatak et al. 2016). One example of this renewal is provided by Italian social cooperatives, which started emerging in the late 1980s and combine characteristics of non-profit voluntary organizations with the cooperative form (Borzaga and Santuari 2001; Mancino and Thomas 2005; Picciotti et al. 2014; Becchetti and Pisani 2015). ${ }^{1}$

It has theoretically been argued that the type of social capital generated in cooperatives differs depending on how they prioritize mutual benefit or public benefit in their model (Hatak et al. 2016). Yet, very few studies to our knowledge have sought to analyze this question empirically. Given this lack of empirical evidence, this article seeks to address the following research question: do the type and level of social capital differ in cooperatives focused on mutual benefit as compared to cooperatives oriented toward public benefit and, if so, how? It does so through the comparative analysis of two renewable energy (RE) cooperatives, BeauVent and Ecopower, located in Flanders, i.e. the Northern part of Belgium. RE cooperatives seem to illustrate the new models of cooperatives mixing mutual benefit and a strong orientation toward public benefit. They enable citizens to collectively own and manage renewable energy projects at the local level. Through this model, citizens produce, invest in and, in some cases, consume renewable energy. Combining economic, social and environmental aims, RE cooperatives and, more generally, community-based energy schemes are increasingly perceived as potentially key actors in the transition toward low-carbon energy systems (Seyfang et al. 2013) and may enhance social acceptability of technologies at the local level (Bauwens 2015).

The two cooperatives studied here differ in a crucial way: in addition to RE generation, Ecopower is an electricity supplier while BeauVent is a generation cooperative only and does not undertake any supply activity. Thus, the traditional identification of members and users is present in the former but absent in the latter. Three different forms of social capital are considered: social identification with the cooperative, generalized interpersonal trust and network structure. The results show that the type and level of social capital differ indeed depending on whether the cooperative is oriented toward mutual or public benefit. On average, an orientation toward public/mutual benefit is associated with higher/lower social identification and stronger/weaker social bonds between members. This relationship is mediated by spatial factors and the structure of social interactions within organizations. Indeed, Ecopower's shift from a public to a mutual benefit orientation when it started supplying electricity was accompanied by sustained organizational and geographical growth which, in turn, increased spatial distance between cooperative members. Moreover, this shift corresponded to a heavier reliance on market interactions. The combination of these two phenomena contributed to a dilution of the social capital of the organization.

This article is structured as follows. The following section offers some theoretical elements about cooperatives and how they relate to the concept of social capital. Section 3 presents the methodology used, Section 4 analyzes the collected data and Section 5 discusses these findings in an attempt to answer our initial question.

1 The development of similar organizational models can be seen in many other national contexts and has been encouraged by the introduction of new legal forms: the social solidarity cooperative in Portugal (1998), the social initiative cooperative in Spain (1999), the French collective interest cooperative (2001), the community interest company in the UK (2004), etc. (Borzaga and Defourny 2001). 


\section{Theoretical framework}

\subsection{The multidimensionality of social capital}

Given the multidimensional character of social capital (e.g. Paldam 2000), we focus on three interrelated yet distinct components of social capital that are commonly distinguished in the literature (see e.g. Brunie 2009): generalized interpersonal trust, social identification with the group and social network structure. First, generalized interpersonal trust refers to the "values and attitudes that influence how people relate to each other and that predispose them to cooperate, trust, understand and empathize with each other' (Brunie 2009: 257). It is a somewhat abstract and pervasive concept as it is not limited to known individuals and translates into a general propensity to trust and cooperate with others beyond specific settings and purposes. In this sense, it differs from the 'thick' trust or strong reciprocity (Gintis 2000) associated with dense and repeated interactions within a well-defined group.

Second, in contrast to the abstraction of generalized trust, social identification, i.e. the perception of belonging to some human aggregate, is associated with membership affiliation to a specific and well-defined group as well as with the emotional and affective significance attached to that membership (Tajfel 1978). The socio-psychological literature on collective action has shown that a strong sense of shared collective identity fosters cooperative behaviors toward the group (Tyler and Blader 2001). This result is supported by extensive evidence from experimental settings and the field (Kramer and Brewer 1984; Brewer and Kramer 1986; Dawes et al. 1988; Brown-Kruse and Hummels 1993; Goette et al. 2006). For instance, Stürmer and Kampmeier (2003), relying on experimental and field data, highlight the importance of group identification as a determinant of community volunteerism and local participation.

Finally, the third component of social capital considered here consists in the network structure (Coleman 1988). Building on the work of Granovetter (1973), two main types of network structures can be distinguished as far as network density is concerned: 'tight-knit', dense social networks in which members have a high number of linkages or 'strong' ties with each other are referred to as having a closed network structure while more diverse social networks in which members have fewer interconnections or 'weak' ties are said to have an open network structure.

\subsection{Social capital and cooperatives}

In the existing literature on social capital and cooperatives, social capital has simultaneously been seen as a necessary condition for organizational development and a potential outcome of cooperative behaviors within organizations in a mutually reinforcing fashion: 'trust lubricates cooperation [...] and cooperation itself builds trust' (Putnam 1993: 171).

Regarding social capital as a condition for the development of cooperatives, founding and maintaining cooperatives and other forms of mutual aid and solidarity requires a group of potential members able to provide the organization with resources which they would access and mobilize through pre-existing social networks between individuals (Defourny 1995; Fonteneau et al. 1999). For instance, cooperatives obtain vital 
resources from their members (Valentinov 2004), such as access to buying markets (in the case of marketing cooperatives) to sales markets (in the case of purchasing cooperatives), to workforce (in the case of producer cooperatives), etc. Thus, members' social capital is a key resource upon which cooperative organizations are built (Spear 2000).

As regards social capital as an outcome of pro-social behaviors within cooperative organizations, it has been argued that face-to-face and frequent contacts in cooperatives foster the development of social capital and norms of trust (Birch and Whittam 2008). In his influential book, Putnam (1993) argued that cooperatives and voluntary associations positively affect social capital by transferring to their members habits of cooperation, solidarity, and public-spiritedness. Likewise, Degli Antoni and Portale (2011) show that inclusive participatory governance in Italian social cooperatives is positively - if unclearly - related to employees' and members' social capital.

In contrast, it can be argued that the importance of social capital (whether seen as a cause or an effect of interactions within firms) is generally lower in for-profit organizations as compared to cooperatives, since the former rely relatively more on market interactions, which typically lack the personal elements of non-market connections, at least where markets approximate the ideal complete-contracting of standard economic models (Bowles 1998; Bowles and Gintis 2002). For sure, this reflects a continuum rather than a clear-cut distinction. First, cooperatives are also economic enterprises that operate on a market, and thus the importance of social capital depends on how personal and market interactions are prioritized in their business model. Second, even in for-profit enterprises, market interactions do not make social capital redundant because trustworthiness and other social norms facilitate market exchange, especially when contracts are incomplete or unenforceable. As Granovetter (1985) argues, market relations are always embedded in social ones to some extent.

For short, social capital is simultaneously a cause and an effect of participation in cooperatives. The objective here is not to disentangle this mutual causation but try and analyze, rather, how institutional and other contextual factors may shape the creation of social capital.

\subsection{The contextualization of social capital}

Social relationships do not emerge ex nihilo. They are embedded in particular institutional and spatio-temporal contexts (Lang and Roessl 2011a, 2011b). What follows focuses on three contextual dimensions shaping social capital that are directly relevant to our concern: the distinction between mutual and public benefit organizations, the spatial dimension of social capital and the relationship between organizational growth and social capital.

\subsubsection{Mutual versus public benefit organizations}

According to the traditional economic theory of the firm, the ownership structure of an organization is defined by the allocation of two formal rights: the residual control rights (Grossman and Hart 1986; Hart and Moore 1990) and the rights to residual surplus (Alchian and Demsetz 1972). Gui (1991) respectively calls the beneficiaries of these two rights the 'dominant category' and the 'beneficiary category'. The residual 
control by the dominant category refers to the ultimate decision-making power which is not shared with other stakeholders according to the statutes or by contract (Bauwens and Lemaître 2014). As for the beneficiary category, it refers to the category owning the rights to the residual surplus of an enterprise. This category, for instance, can be buyers or sellers (through lower or higher prices respectively), consumers of non-excludable goods, aid recipients (getting goods or services for free), workers (through better pay) and investors (through higher return on investments). ${ }^{2}$ These criteria enable us to derive one crucial distinction between SE organizations and traditional for-profit firms: the latter are typically defined by the fact that investors are actually the dominant category and the beneficiary category while dominant and beneficiary categories are never investors in SE organizations: they may be consumers, workers, volunteers, donors, and so on, i.e. groups whose main role is not to invest money and whose main concern is not to maximize return on investment.

Gui (1991) makes a further distinction among SE organizations between, on the one hand, 'mutual benefit' organizations, and, on the other, 'public benefit' organizations. In the former, the dominant and the beneficiary categories coincide, i.e. the dominant category can manage the organization for its own benefits (e.g. consumer cooperative, credit cooperative, worker cooperative, mutual societies as well as member-centered associations in fields of leisure, lobbying, joint representation, etc.), while in the latter there is a non-coincidence between the dominant and the beneficiary category (e.g. humanitarian associations such as Oxfam among many others helping disadvantaged people).

Traditional cooperative firms operating in fields such as agriculture, banking or retail, act exclusively or primarily in the interest of their members, who are also the owners. In this sense, they are typical examples of mutual benefit organizations. As just mentioned, their dominant and beneficiary categories are thus constituted by their member-users, understood in a broad sense: savers in a credit cooperative, agricultural producers in an agricultural marketing or purchasing cooperative, consumers in a consumer cooperative, workers in a worker cooperative, etc. (Hansmann 1996). In new models of cooperatives, the beneficiary category, which has the right on residual surplus, is no longer merely constituted by the members, but may include non-member third parties (Mori 2014). For instance, if an energy cooperative carries out electricity supply activities with the purpose of getting the lowest possible price for its customer-members, it would be considered an ordinary mutual benefit organization. However, it would be a public benefit organization if its central objective were to help the largest possible number of people, whether they are members or not, to reduce their energy bills. For this reason, these cooperatives "can typically be described as "social enterprises", together with other organizational models combining a commercial activity with the pursuit of social aims' (Huybrechts and Mertens 2014: 197).

This is not to deny the specific 'social' functions exerted by traditional cooperatives as compared to for-profit firms, which are reflected in their mission (the satisfaction of

2 The distribution of the surplus is not necessarily carried out in an explicit way - under the form of dividends or boni, for instance - but can also be implicit - as in the case of discounts for members or an increased quality of goods and services. In this perspective, the expression of 'potential surplus' is used to designate the surplus distributed by the organization both in explicit and implicit ways to the beneficiary category. 
other needs than the remuneration of capital), their governance structure (the primacy of persons over capital and the principle of democracy) and the various obligations of 'external' surplus destination included in ICA principles (Fici 2013). ${ }^{3}$ The difference between mutual and public benefit, therefore, is more a matter of degree than kind. However, besides the already high level of 'publicness' common to all cooperatives (at least in principle) in comparison with classical firms, public benefit cooperatives have an extra element constituted by their explicit pursuit of the general interest (Fici 2009). ${ }^{4}$

The orientation toward mutual or public benefit is likely to influence the type and/or level of social capital in SE organizations. In a conceptual paper focusing on the case of cooperatives, for instance, Hatak et al. (2016) argue that the orientation toward mutual or public benefit is associated with different types of social capital. ${ }^{5}$ More precisely, mutual benefit cooperatives are said to rely on a closed network structure associated with strong ties between members and group-specific trust. Conversely, public benefit cooperatives are supposed to be built upon an open network structure associated with weak ties between members and generalized trust.

\subsubsection{The spatial dimension of social capital}

In addition to the distinction between mutual and public benefit, the development of social capital is likely to be mediated by spatial factors (Rutten et al. 2010). First, by facilitating direct social interactions and face-to-face communication, spatial closeness further facilitates the activation of social norms in the group (Byrne et al. 2015). Indeed, shorter physical distances between actors in general mean lower interaction costs than longer distances (Westlund 1999). Second, social networks in rural areas differ from those in urban settings in terms of diversity and density (Beggs et al. 1996). Onyx and Bullen (2000) describe the social capital found in rural areas as 'bonding' social capital, for pointing to higher degrees of mutual trust and support found among residents in smaller communities than in urban areas.

\subsubsection{Organizational growth and social capital}

Finally, social capital may be expected to be negatively affected by the growth of SE organizations. As business operations become more complex and membership becomes

3 These obligations include the constitution of unshareable reserves, benefiting future generations of members, the provision of support to the cooperative movement and the implementation of policies for the sustainable development of the community.

4 Note that the 'publicness' of an organization also partly depends on the nature of the good produced and/or commercialized and, in particular, on whether the product is a 'private' or a 'public' good. In economics, a good is private when the producer bears all the costs of production and a single consumer enjoys all the benefits of consumption. With public goods, by contrast, it is impossible to exclude individuals who have not paid for the good from its consumption. Thus, when an organization produces a public good or an impure public good, it can be argued that it is relatively more oriented toward public benefit, compared to an organization that produces a fully private good. This is true for RE cooperatives compared to traditional cooperatives because renewable energy can be conceptualized as an impure public good (Kotchen and Moore 2007). This aspect, however, is not considered here.

$5 \quad$ Hatak et al. (2016) use a different terminology. They refer to mutual and public benefit cooperatives as 'member-focused' and 'third-party-focused' cooperatives respectively. 
Table 1 - General characteristics of cooperatives

\begin{tabular}{lcc}
\hline & Ecopower & BeauVent \\
\hline Year of creation & 1991 & 2000 \\
Number of full-time equivalent workers & 22 & 5.37 \\
Number of members & 47,419 & 2,391 \\
Total cooperative capital (in euros) & $48,328,750$ & $4,781,500$ \\
Price of one share (in euros) & 250 & 250 \\
\hline
\end{tabular}

Source: Created by author based on 2013 data provided by the cooperatives.

larger and more heterogeneous, the members' support to their organization fades (Jones and Kalmi 2012). For instance, in an empirical survey among the members of a large traditional Swedish cooperative, Nilsson et al. (2009) show that when members consider the cooperative to be too large and too complex to be controlled by the membership, member satisfaction and involvement levels decrease, which in turn is associated with poor trust in the cooperative board and management. In this perspective, Feng et al. (2016) show empirically that social capital, expressed in terms of member involvement, trust, satisfaction and loyalty, correlates negatively with size.

To sum up, the goal of this paper is to explore how the type and level of social capital differs in mutual and public benefit organizations, while taking into account other contextual factors, such as the spatial dimension of social capital and organizational growth.

\section{$3 \quad$ Methodology}

\subsection{Field setting}

The two cooperatives studied here share a number of features: they are located in Flanders (Belgium); they operate exclusively with renewable energy; they are owned by individual members who each have equal voting rights and receive limited dividends; and they are part of the Belgian federation of renewable energy cooperatives REScoop.be. Where they clearly differ, however, is in their size and in the services they provide to their members. First of all, Ecopower is an electricity supplier while BeauVent is not. ${ }^{6}$ When Ecopower started supplying electricity, i.e. when the Belgian electricity market was liberalized in 2003 , its membership rose dramatically as individuals had to become cooperative members to be supplied with green electricity. Hence, a second important difference is size: as a result of its activity of electricity supply, Ecopower has grown substantially and is much larger than BeauVent. In 2014, while the latter had about 2,400 members, Ecopower had over 47,400 and was thus almost twenty times as large (Table 1).

These characteristics enable us to compare different groups of members within and across the two organizations. In particular, besides comparing it with BeauVent,

6 Still, although BeauVent itself does not supply electricity, an agreement between both cooperatives stipulates that BeauVent members can be supplied with electricity by Ecopower even without being formal members of the latter. 
it is meaningful to distinguish between three phases in Ecopower's organizational development corresponding to different mixes of public and mutual benefit. In the first phase, from its creation over 1991-99, the purpose of the cooperative was to gather small amounts of money from motivated individuals to finance the refurbishment of small hydropower installations. As such, over this period, the cooperative itself was not involved in any energy production activities. As a result, this phase is fully characterized by an orientation toward public benefit, since there was no residual surplus to be distributed to members. The second phase corresponds to the 2000-02 period. It started with the installation of three wind turbines in the city of Eeklo, which were financed by a recruitment campaign launched in 2000. Over this period, the cooperative was relatively more oriented toward mutual benefit compared to the previous phase; this is because the cooperative started distributing some of its residual surplus to its members under the form of dividends (the cooperative distributed 6 per cent dividends in each year of that period). The third phase is identified with the start of electricity supply in 2003 and extends to the present. Parallel to its supply activities, Ecopower continues to invest in RE projects. This phase is characterized by an even stronger orientation toward mutual benefit relative to the two previous phases, because aside from distributing dividends, Ecopower also started supplying its members with electricity at production cost, i.e. without making a profit. As an additional benefit attached to membership, Ecopower members then had the possibility to switch to an electricity tariff that, in most cases, was cheaper than that of other suppliers. ${ }^{7}$

\subsection{Data collection}

Quantitative data were collected by an online questionnaire survey conducted between May and June 2014 to address the two research questions. The cooperatives provided members' email addresses. 36,642 emails were sent to Ecopower members and 849 were sent to BeauVent members. In addition, a paper version of the questionnaire was handed out during the General Assembly of both organizations with the objective of reaching a profile of people who would not have been reached by the online questionnaire. Indeed, the participants to the General Assemblies are typically an older public with a presumably lower usage of the Internet. 195 paper versions of the questionnaire were handed out in the general assembly of Ecopower and 43 during that of BeauVent. All in all, out of the 37,729 copies distributed in total, 4061 respondents participated in the survey. This represents a response rate of 10.8 per cent.

Different biases could arise from survey measures, such as selection issues or measurement errors. As regards the representativeness of our sample, while our

7 It should be noted that the dividends and electricity supply at production cost should be considered simultaneously to accurately determine the orientation toward mutual benefit. If, for instance, Ecopower had decreased its dividends when it started supplying electricity, the organization would not have been more oriented toward mutual benefit compared to the previous period, because the two effects on members' surplus would have cancelled out. This was not the case, however, since Ecopower continued distributing 6 per cent dividends after 2003. Thus, the policy of dividend distribution being unchanged, the possibility of being supplied at a cheaper price compared to those of competitors does indeed result in a higher orientation toward mutual benefit. 
Table 2 - Weighting factors used in the data analysis

\begin{tabular}{lccccc}
\hline \multicolumn{5}{c}{ Period of membership (in years) } \\
\cline { 2 - 5 } & $0 \leq \boldsymbol{x}<5$ & $5 \leq \boldsymbol{x}<10$ & $10 \leq \boldsymbol{x}<15$ & $15 \leq \boldsymbol{x}<20$ & $20<\boldsymbol{x}$ \\
\hline Antwerp & 1.056 & 0.845 & 0.724 & 0.015 & 0.120 \\
Brussels & 1.170 & 0.936 & 0.802 & 0.016 & 0.132 \\
Limburg & 1.240 & 0.993 & 0.850 & 0.017 & 0.140 \\
East-Flanders & 1.199 & 0.960 & 0.822 & 0.016 & 0.136 \\
Flemish Brabant & 1.069 & 0.856 & 0.733 & 0.015 & 0.121 \\
West-Flanders & 1.325 & 1.061 & 0.909 & 0.018 & 0.150 \\
Other & 1.170 & 0.936 & 0.802 & 0.016 & 0.132 \\
\hline
\end{tabular}

Source: Created by author based on 2013 data provided by the cooperatives.

response rate averages that obtained in similar surveys (e.g. Litvine and Wüstenhagen, 2011), drawing firm conclusions about the generality of members calls for caution. To improve the representativeness of the sample, we have weighted our sample data so that the characteristics of the sample better match some characteristics of the population as a whole. More precisely, information about the location of members and their period of membership (i.e. how long individuals have belonged to the cooperative) was available for the whole underlying population of cooperative members. In order to improve the representativeness of the collected sample regarding these variables, their distribution was computed for the whole population and compared to their distribution in the sample. Weights were then assigned to the observations with the view of reproducing the distributions of the aforementioned variables in the collected sample, using post-stratification adjustments (Table 2). Post-stratification classifies the sample by group or stratum based on the characteristics of the population and then weights individuals in each group up to the population total in that group, with values above 1.00 boosting the weight given to data collected from participants in the relevant group, and vice versa.

\subsection{Variables}

\subsubsection{Measures of social capital}

Generalized interpersonal trust (TRUST) was measured using three items selected from the World Value Survey (WVS): 'Would you say that most people can be trusted, or that you can't be too careful in dealing with people?', 'Do you think that most people would try to take advantage of you if they got the chance, or would they try to be fair?' and 'Would you say that most of the time people try to be helpful or that they are mostly looking out for themselves?'. They were answered through a seven-point Likert scale. These three items were then aggregated into a single summative scale (Cronbach's alpha $=0.82$ ).

Social identification (SOCIDENT) was measured by five items adapted from existing studies (Tyler and Blader 2001; Stürmer and Kampmeier 2003). Social identification entails a cognitive component (a cognitive sense of belonging to a group), an affective component (a sense of emotional involvement with the group) and an evaluative 
Table 3 - Number and proportions of members by category

\begin{tabular}{lcccc}
\hline Category & $\begin{array}{c}\text { Number of } \\
\text { members in the } \\
\text { population (\%) }\end{array}$ & $\begin{array}{c}\text { Number of } \\
\text { members in the } \\
\text { sample }\end{array}$ & $\begin{array}{c}\text { Proportion in the } \\
\text { sample without } \\
\text { weighting factors }\end{array}$ & $\begin{array}{c}\text { Proportion in the } \\
\text { sample with } \\
\text { weighting factors }\end{array}$ \\
\hline Ecopower 1 & $47(0.09 \%)$ & 43 & $1.32 \%$ & $0.071 \%$ \\
Ecopower 2 & $656(1.32 \%)$ & 94 & $2.72 \%$ & $2.14 \%$ \\
Ecopower 3 & $46,716(93.79 \%)$ & 3,141 & $90.75 \%$ & $92.72 \%$ \\
BeauVent & $2,391(4.80 \%)$ & 183 & $5.29 \%$ & $5.07 \%$ \\
Total & $49,810(100 \%)$ & $3,461^{8}$ & $100 \%$ & $100 \%$ \\
\hline
\end{tabular}

Source: Created by author based on 2013 data provided by the cooperatives.

component (a positive or negative value attached to membership). Accordingly, we sought to collect indicators of these different aspects. The cognitive component was measured by three items: 'I have a lot in common with the other members of the cooperative', 'Being a member of the cooperative is an important part of whom I am', and 'I feel attached to the other cooperative members'. One item was used to measure the evaluative component, or group-based self-esteem: 'I am proud to be part of the cooperative', and another one to measure the affective component: 'I like talking about the cooperative in the presence of others'. They were answered through a five-point Likert scale, from $1=$ 'completely disagree' to $5=$ 'completely agree'. Together, the five items formed an internally consistent scale (Cronbach's alpha $=0.86$ ).

Finally, in order to assess member linkages with other cooperative members (NETWORK), respondents were asked whether they had other members within their direct social network (relatives, friends, and neighbors). So, this variable captures the density of the network of cooperative members.

\subsubsection{Explanatory variables}

To analyze social capital in relation to the orientation toward mutual or public benefit, members were asked in what year they joined their cooperative so that their period of membership (in years) could be computed. The members for whom this information was missing were excluded from the analysis. The sample of Ecopower members was then divided into three categories of cooperative members, which correspond to the three phases that Ecopower went through described in Section 3.1: those who joined the cooperative during its first phase (1991-99), those who joined it after the installation of the first wind turbines (2000-02) and those who joined it after it became an electricity supplier (2003-today). In the remainder of this article, the different groups are referred to in the following way: the three successive cohorts of Ecopower members are respectively called 'Ecopower 1', 'Ecopower 2' and 'Ecopower 3', and BeauVent members are called 'BeauVent'. Table 3 presents the number and proportions of members in each category, based on data for the entire population and for our sample. As shown in the table, Ecopower 3 is much larger than the other three categories. The proportions of the different categories in the sample also indicate the presence of a small sample bias: Ecopower 1, Ecopower 2 and BeauVent are slightly overrepresented and

8 This figure includes the members belonging to both cooperatives. 
Ecopower 3 underrepresented as compared to proportions in the population. However, the introduction of weighting factors contributes to reduce these biases.

In order to better isolate the differences between organizations, individuals who were members of both cooperatives were excluded from the analysis. The final sample used in the analysis contained 3,337 observations.

\subsubsection{Control variables}

As control variables, data were collected for basic socio-demographic variables (gender, education, age, income). Respondents were also asked to indicate their postcode so that their location could be determined.

In addition, data were collected for indicators of socio-psychological variables, including feelings of distributive and procedural justice ${ }^{9}$ and pro-environmental orientation. As regards individuals' feelings of procedural and distributive justice, judgements about justice related to society considered globally were accessed by adapting items used in organizational psychology (Colquitt 2001) and in a survey about representations of social justice (Jacquemain 1995). Individuals' pro-environmental orientation was captured through two dimensions: pro-environmental self-identity and daily behaviors. In order to measure the degree of pro-environmental self-identity, six items from existing questionnaires were selected and adapted (Fielding et al. 2008; Castro et al. 2009; Whitmarsh and O'Neill 2010). These items measure on a five-point scale the extent to which the respondent perceives himself as a person concerned with environmental issues. To measure respondents' pro-environmental engagement in terms of daily behaviors, proenvironmental behaviors were selected from existing studies (Delacolette et al. 2011), such as 'walk or ride a bike to travel short distances', 'avoid plastic bags in shops' or 'turn off the tap while brushing my teeth'. Respondents were asked to indicate on a five-point scale the frequency at which they executed each of the five actions over the last fortnight. The items were then aggregated into a single summative scale.

Table 4 reports the specific statements for feelings of procedural and distributive justice and pro-environmental orientation along with statistics to test for internal consistency (item-total correlations and Cronbach's alpha). The Cronbach's alpha indicates good internal consistency. ${ }^{10}$

In addition, members were asked about their motivations to join the cooperative. Motivation indicators consist of a series of ordinal variables which have been constructed by asking respondents to rate on a five-point scale (from $1=$ 'not at all' to $5=$ 'completely') the extent to which a specific motivation had played a role in their decision to join the cooperative. More specifically, questions were included to assess the importance of return on investment and low electricity price. Furthermore, members were asked to what extent they valued the local production of renewable energy, the democratic control

9 Distributive justice involves the subjective individual estimation of the way benefits and costs - which may not be merely material - are distributed within a group. Procedural justice concerns the subjectively perceived fairness of the processes that resolve disputes and allocate resources.

10 The dimensionality of each series of items has also been tested by conducting exploratory factor analyses. In each case, the results highlight that the items reflect a unique dimension and thus confirm the relevance of aggregating them into one single summated score. 
Table 4 - Item-total correlation and Cronbach's alpha for the different scales

\begin{tabular}{lc}
\hline & \\
& $\begin{array}{l}\text { Item-total } \\
\text { Correlation and } \\
\text { Cronbach's alpha }\end{array}$ \\
\hline Pro-environmental orientation & 0.63 \\
1. I feel concerned about climate change. & 0.45 \\
2. I think that human activities are one of the main causes of climate change. & 0.65 \\
3. I am the type of person who cares about ecology. & 0.68 \\
4. I think of myself as an eco-responsible consumer. & 0.68 \\
5. I want to feel that I personally contribute to the protection of the & \\
environment. & 0.57 \\
6. I like that my family or my friends see me as someone concerned by the & \\
environment & 0.44 \\
7. Make short distances on foot or by bike & 0.45 \\
8. Avoid plastic bags in shops & 0.48 \\
9. Reuse old plastic bags & 0.40 \\
10. Buy fruit and vegetables grown locally rather than imported & 0.40 \\
11. Turn off the tap while brushing my teeth & 0.84 \\
Cronbach's alpha & \\
Feelings of distributive justice & 0.50 \\
1. In our country, there are too many social inequalities. & 0.51 \\
2. For an economy to work well there must necessarily be rich and poor & \\
3. Seople. & 0.58 \\
Becial equality is a good thing, but we have already been too far in & \\
Cronbach's alpha & 0.72 \\
Feelings of procedural justice & \\
1. Policy-makers care about what the population thinks. & 0.69 \\
2. I have the impression that policy-makers take my opinion into account. \\
3. I think that political decisions most of the time are respectful of moral and \\
ethical values. & 0.73 \\
Cronbach's alpha & 0.61 \\
\hline
\end{tabular}

Source: Created by author.

of organizations and the influence of other people's advice in their decision to join the cooperative.

Finally, data about the frequency of attendance to general assemblies was also collected. Respondents had to indicate on a four-point scale the frequency at which they attended general assemblies ( 1 = 'never', $2=$ 'sometimes', $3=$ 'often', $4=$ 'always').

For simplicity of the analysis, socio-psychological characteristics were transformed into binary variables taking the value 1 if the respondent's score was above the median and 0 otherwise. Table 5 reports the description and summary statistics of all the dependent and explanatory variables used in the analysis.

\subsection{Data analysis}

An ordered probit model was used to estimate the intensity of social identification and generalized interpersonal trust, since these variables are ordinal. The ordered probit 
Table 5 - Descriptive overview of the variables

\begin{tabular}{|c|c|c|c|c|}
\hline Variable & Description & $N$ & Mean & SD \\
\hline \multicolumn{5}{|c|}{ Measures of social capital } \\
\hline TRUST & Ordinal variable taking the value 1 to 7 & 3299 & 4.57 & 1.09 \\
\hline SOCIDENT & Ordinal variable taking the value 1 to 5 & 3327 & 3.25 & 0.89 \\
\hline NETWORK & $\begin{array}{l}=1 \text { if member has other coop members in } \\
\text { social networks }\end{array}$ & 3294 & 0.58 & 0.49 \\
\hline \multicolumn{5}{|l|}{ Control variables } \\
\hline EDUCATION & $\begin{array}{l}\text { Ordinal variable taking the value } 1 \text { if } \\
\text { secondary education, } 2 \text { if superior } \\
\text { non-university education and } 3 \text { if } \\
\text { university education }\end{array}$ & 3273 & 3.06 & 0.77 \\
\hline INCOME & $\begin{array}{l}\text { Ordinal variable taking the value } 1 \text { if } \\
\text { household income }<2000 € / \text { month, } 2 \text { if } \\
2000<\text { household income } \\
<€ 4000 / \text { month and } 3 \text { if household } \\
\text { income }>€ 4000 / \text { month }\end{array}$ & 2945 & 2.05 & 0.67 \\
\hline GENDER & $=1$ if individual is a man & 3322 & 0.82 & 0.38 \\
\hline AGE & Age in years & 3333 & 49.07 & 11.99 \\
\hline DEMOCRATIC & $\begin{array}{l}=1 \text { if importance of democratic control of } \\
\text { organizations }=4 \text { or } 5\end{array}$ & 3337 & 0.48 & 0.50 \\
\hline GREEN & $\begin{array}{l}=1 \text { if importance of local production of } \\
\text { renewable energy }=4 \text { or } 5\end{array}$ & 3337 & 0.71 & 0.46 \\
\hline $\mathrm{ROI}$ & $=1$ if importance of $\mathrm{ROI}=4$ or 5 & 3337 & 0.26 & 0.44 \\
\hline PRICE & $\begin{array}{l}=1 \text { if importance of electricity price }=4 \text { or } \\
5\end{array}$ & 3337 & 0.55 & 0.50 \\
\hline ADVICE & $\begin{array}{l}=1 \text { if importance of other members' advice } \\
=4 \text { or } 5\end{array}$ & 3337 & 0.18 & 0.39 \\
\hline PROENVORIENT & $\begin{aligned}= & 1 \text { if pro-environmental orientation }> \\
& \text { median }\end{aligned}$ & 3337 & 0.45 & 0.50 \\
\hline DISTRIBUTIVE & $\begin{aligned}= & 1 \text { if feelings of distributive justice }> \\
& \text { median }\end{aligned}$ & 3337 & 0.43 & 0.49 \\
\hline PROCEDURAL & $\begin{array}{l}=1 \text { if feelings of procedural justice }> \\
\text { median }\end{array}$ & 3337 & 0.47 & 0.50 \\
\hline AGM & $\begin{array}{l}=1 \text { if frequency of participation = 'often' or } \\
\text { 'always' }\end{array}$ & 3337 & 0.03 & 0.18 \\
\hline PROFESSIONAL & $=1$ if individual is a professional & 3245 & 0.03 & 0.17 \\
\hline SELFEMPLOYED & $=1$ if individual is self-employed & 3245 & 0.04 & 0.20 \\
\hline WORKER & $=1$ if individual is a worker & 3245 & 0.17 & 0.38 \\
\hline EMPLOYEE & $=1$ if individual is an employee & 3245 & 0.06 & 0.24 \\
\hline EXECUTIVE & $=1$ if individual is an executive & 3245 & 0.39 & 0.49 \\
\hline OTHERSTATUS & $\begin{array}{l}=1 \text { if individual has another employment } \\
\text { status }\end{array}$ & 3245 & 0.05 & 0.23 \\
\hline INACTIVE & $\begin{array}{l}=1 \text { if individual is inactive (student, retired, } \\
\text { etc.) }\end{array}$ & 3245 & 0.25 & 0.43 \\
\hline
\end{tabular}

Source: survey (2014).

model can be derived from a latent variable model (Wooldridge 2002). This is to say that it assumes that the responses on the indicators of social capital are the result of an underlying latent variable, $y_{i}^{*}$, which is unobservable but can be defined by a deterministic component $\left(S_{i}\right)$ that is observable and a stochastic error term $\left(\varepsilon_{i}\right)$ that is not observable:

$$
\boldsymbol{y}_{i}^{*}=\boldsymbol{S}_{i}+\varepsilon_{i}
$$


Assume that $S_{i}$ can be represented by the following additive linear function:

$$
\boldsymbol{S}_{\boldsymbol{i}}=\boldsymbol{\beta}_{1} \boldsymbol{E} 1_{i}++\boldsymbol{\beta}_{2} E 2_{i}+\boldsymbol{\beta}_{3} \boldsymbol{B}_{i}+\sum_{j=1}^{n} \boldsymbol{\beta}_{j} \boldsymbol{X}_{i, j}
$$

where $E 1_{i}, E 2_{i}$ and $B_{i}$ are dummies that indicate the belonging to Ecopower 1, Ecopower 2 and BeauVent respectively, and $X_{i}$ is a $n$ length vector of individual $i$ 's characteristics. Hence, the coefficients for the three cohorts of cooperative members need to be interpreted with reference to Ecopower 3, i.e. those who joined after the cooperative became an electricity supplier. The ordered probit model assumes that the observed indicator of social capital $\left(y_{i}\right)$ equals $j$ if the latent variable, $\mathrm{y}_{\mathrm{i}}^{*}$, crosses an unknown threshold:

$$
\boldsymbol{y}_{\boldsymbol{i}}=\boldsymbol{j} \quad \text { if } \propto_{j}-1<\boldsymbol{y}_{\boldsymbol{i}^{*}} \leq \propto_{\boldsymbol{j}}
$$

where $\propto_{j-1}<\propto_{j}$ are unknown threshold parameters. As $y_{i}^{*}$ crosses increasing threshold levels (from $\propto_{0}=-\infty$ to $\propto_{J}=\infty$ ), the observed indicator of social capital moves up the scale (1-5). The probability that individual $i$ will report the level $j=1, \ldots, 5$ is given by

$$
\boldsymbol{P}_{i j}=\operatorname{Prob}\left(\propto_{j-1}<\boldsymbol{S}_{i}+\boldsymbol{\varepsilon}_{i} \leq \propto_{j}\right)=\operatorname{Prob}\left(\propto_{j-1}-\boldsymbol{V}_{\boldsymbol{i}}<\boldsymbol{\varepsilon}_{\boldsymbol{i}} \leq \propto_{j}-\boldsymbol{S}_{\boldsymbol{i}}\right)
$$

Using equation (3),

$$
\boldsymbol{P}_{i j}=\boldsymbol{\Phi}\left(\propto_{j}-\boldsymbol{\beta}_{1} \boldsymbol{E} 1_{i}-\boldsymbol{\beta}_{2} \boldsymbol{B}_{i}-\sum_{j=1}^{n} \boldsymbol{\beta}_{j} \boldsymbol{X}_{i, j}\right)-\boldsymbol{\Phi}\left(\propto_{j-1}-\boldsymbol{\beta}_{1} E 1_{i}-\boldsymbol{\beta}_{2} \boldsymbol{B}_{i}-\sum_{j=1}^{n} \boldsymbol{\beta}_{j} \boldsymbol{X}_{i, j}\right)
$$

where $\Phi($.$) is the cumulative density function for standard normally distributed errors.$ Parameters were estimated by maximum likelihood.

To estimate the presence of other members in social networks, we used a probit model, since this variable is binary. The specification used is

$$
\begin{aligned}
\boldsymbol{E}\left(\boldsymbol{N}_{\boldsymbol{i}} \mid \boldsymbol{E} 1_{i}, E 2_{i}, \boldsymbol{B}_{i}, x\right) & =\operatorname{Prob}\left(\boldsymbol{N}_{i}=1 \mid \boldsymbol{E} 1_{i}, E 2_{i}, \boldsymbol{B}_{i}, x\right) \\
& =\Phi\left(\boldsymbol{\alpha}_{1} \boldsymbol{E} 1_{i}+\boldsymbol{\alpha}_{2} \boldsymbol{B}_{\boldsymbol{i}}+\boldsymbol{\alpha}_{3} \boldsymbol{x}\right)
\end{aligned}
$$

where $N_{i}$ is a binary variable indicating whether individual $i$ has other cooperative members in her social network (friends, relatives, neighbors) and $x$ is a $n$ length vector of individual $i$ 's characteristics. The coefficients are directly interpretable in terms of marginal effects.

A further adjustment is made on the covariance matrix of the estimates. Since we can assume that correlation is present between the residuals of members within the same cohort, we use cluster-robust standard errors. 


\section{Table 6 - Mean scores of measures of social capital for the categories of cooperative members}

\begin{tabular}{lcccr}
\hline & Ecopower 1 & Ecopower 2 & Ecopower 3 & BeauVent \\
\hline SOCIDENT & $3.78(43)$ & $3.61(93)$ & $3.23(3132)$ & $3.48(59)$ \\
TRUST & $4.69(43)$ & $4.86(92)$ & $4.56(3105)$ & $4.51(59)$ \\
NETWORK & $0.70(43)$ & $0.67(92)$ & $0.58(3103)$ & $0.70(56)$ \\
\hline
\end{tabular}

Source: Survey (2014). Numbers in parentheses are sample sizes.

\section{$4 \quad$ Results}

\subsection{Mutual versus public benefit}

Before presenting the results of the econometric analysis, Table 6 compares the mean scores of SOCIDENT, TRUST and NETWORK for the four categories of cooperative members.

As regards SOCIDENT and NETWORK, members belonging to Ecopower 3 present the lowest score on average, while those belonging to Ecopower 1 have the highest score. The scores of Ecopower 2 and BeauVent members fall in between. For both indicators, these differences are statistically significant (SOCIDENT: $\mathrm{H}(3)=36.66, p=$ 0.000. NETWORK: $\left.\chi^{2}(3)=8.75, p=0.033\right)$ Regarding TRUST, members belonging to Ecopower 2 have the highest interpersonal trust on average, whereas BeauVent members present the lowest average score. These differences are also statistically significant $(\mathrm{H}(3)=7.047, p=0.070){ }^{11}$

Estimation results for the multivariate regressions are displayed in Table 7. Tukey-Pregibon link specification tests were performed after each regression (Hilbe 2009). In each case, the link test revealed no problem with our specifications. Columns (1)-(3) correspond to our first dependent variable, SOCIDENT, while columns (5) and (6) correspond to TRUST and NETWORK respectively. Different specifications are estimated and control variables are added gradually. Column (1) exclusively contains the cooperative dummies and basic socio-demographic variables. Column (2) introduces the motivations to join the cooperative as additional control variables. Next, columns (3)(5) include socio-psychological variables and the frequency of participation to general meetings.

As shown in column (1), belonging to Ecopower 1, Ecopower 2 and BeauVent appreciably increases the likelihood that the respondent strongly identifies with the cooperative. Among control variables, education has a significantly positive marginal effect, while income influences the outcome negatively.

Column (2) introduces the effects of the motivations to join the cooperative. The marginal effects of belonging to Ecopower 1, Ecopower 2 and BeauVent are still very significantly positive. In addition, the production of renewable energy, the democratic nature of cooperative governance and advice of other members are positively associated with social identification.

11 For a more detailed comparison between these four groups, see Bauwens (2016). 
Table 7 - Social capital and mutual versus public benefit

\begin{tabular}{|c|c|c|c|c|c|}
\hline & \multicolumn{3}{|c|}{ Social identification } & \multirow{2}{*}{$\begin{array}{c}\begin{array}{c}\text { Generalized } \\
\text { trust }\end{array} \\
\text { Ordered probit }\end{array}$} & \multirow{2}{*}{$\begin{array}{c}\begin{array}{c}\text { Members in } \\
\text { social network }\end{array} \\
\text { Probit }\end{array}$} \\
\hline & Ordered probit & Ordered probit & $\begin{array}{c}\text { Ordered } \\
\text { probit }\end{array}$ & & \\
\hline & $(1)$ & (2) & (3) & (4) & (5) \\
\hline ECOPOWER1 & $0.54^{\star \star *}(0.01)$ & $0.36^{* \star \star}(0.01)$ & $0.27^{\star \star \star}(0.01)$ & $-0.11^{\star \star \star}(0.01)$ & $0.09^{\star \star \star}(0.00)$ \\
\hline ECOPOWER2 & $0.45^{* \star *}(0.00)$ & $0.49^{* * \star}(0.00)$ & $0.39^{* * \star}(0.00)$ & $0.19^{* \star *}(0.00)$ & $0.12^{\star \star \star}(0.00)$ \\
\hline BEAUVENT & $0.28^{\star \star \star}(0.00)$ & $0.24^{\star \star \star}(0.00)$ & $0.07^{* \star}(0.03)$ & $-0.05^{* \star}(0.02)$ & $0.07^{\star \star \star}(0.01)$ \\
\hline EDUCATION & $0.07^{\star \star \star}(0.01)$ & $0.04^{\star \star \star}(0.01)$ & $-0.02^{* \star \star}(0.01)$ & $0.12^{* \star *}(0.00)$ & $0.02^{\star \star \star}(0.01)$ \\
\hline INCOME & $-0.05^{* \star *}(0.01)$ & $0.02^{* \star \star}(0.01)$ & $0.04^{* \star \star}(0.01)$ & $0.10^{* * *}(0.01)$ & $0.01(0.01)$ \\
\hline GENDER & $0.04(0.02)$ & $0.06^{\star \star \star}(0.02)$ & $0.12^{* * \star}(0.01)$ & $-0.06^{* \star}(0.03)$ & $-0.01(0.02)$ \\
\hline AGE & $0.01^{* * \star}(0.00)$ & $0.01^{* \star \star}(0.00)$ & $0.01^{* * *}(0.00)$ & $0.01^{* * *}(0.00)$ & $0.00^{\star \star \star}(0.00)$ \\
\hline DEMOCRATIC & & $0.66^{\star \star \star}(0.01)$ & $0.62^{* \star \star}(0.02)$ & $0.08^{\star \star \star}(0.01)$ & $0.03^{\star \star \star}(0.01)$ \\
\hline GREEN & & $0.63^{\star \star \star}(0.01)$ & $0.47^{\star \star \star}(0.01)$ & $0.14^{* \star *}(0.03)$ & $-0.03^{\star \star \star}(0.01)$ \\
\hline $\mathrm{ROI}$ & & $-0.02(0.01)$ & $0.04^{* * \star}(0.02)$ & $-0.17^{\star \star \star}(0.00)$ & $0.06^{\star \star \star}(0.01)$ \\
\hline PRICE & & $0.04^{* \star}(0.02)$ & $0.09^{* * *}(0.02)$ & $-0.07^{\star \star \star}(0.01)$ & $-0.04^{\star \star \star}(0.01)$ \\
\hline ADVICE & & $0.26^{\star \star \star}(0.03)$ & $0.26^{* * \star}(0.02)$ & $0.08^{* *}(0.02)$ & $0.13^{\star \star \star}(0.02)$ \\
\hline PROENVORIENT & & & $0.60^{* \star *}(0.02)$ & $0.12^{* * *}(0.03)$ & $0.06^{\star \star \star}(0.01)$ \\
\hline DISTRIBUTIVE & & & $-0.13^{* * \star}(0.02)$ & $-0.29^{\star \star \star}(0.01)$ & $-0.01^{\star \star \star}(0.00)$ \\
\hline PROCEDURAL & & & $0.17^{\star \star \star}(0.02)$ & $0.47^{* * *}(0.01)$ & $0.02^{\star \star \star}(0.00)$ \\
\hline AGM & & & $0.55^{* \star *}(0.10)$ & $-0.08(0.09)$ & $0.11^{* * *}(0.02)$ \\
\hline $\begin{array}{l}\text { Fixed effects for } \\
\text { professional } \\
\text { status }\end{array}$ & YES & YES & YES & YES & YES \\
\hline$N$ & 2866 & 2866 & 2866 & 2867 & 2839 \\
\hline Pseudo- $R^{2}$ & 0.004 & 0.0430 & 0.060 & 0.029 & 0.024 \\
\hline
\end{tabular}

Source: Survey (2014). Note: Cluster-robust standard errors are in parentheses. ${ }^{*} p<.10 ;{ }^{* *} p<.05 ;{ }^{* * *} p<.01$.

Column (3) shows that when controlling for socio-psychological characteristics, the positive marginal effects of belonging to Ecopower 1, Ecopower 2 and BeauVent are still strongly significant. Pro-environmental orientation and procedural feelings of justice have a significantly positive marginal effect on social identification. This indicates that members who have strong environmental concerns and who think that the world is fair from a procedural perspective tend to identify more with the cooperative. By contrast, feelings of distributive justice are negatively related with SOCIDENT. This suggests that on average, those who think that the world is fair from a distributive perspective identify less with the cooperative.

A frequent participation to general assemblies is significantly positively associated with social identification. This result is likely to reflect a two-way causal relationship: a strong identification with the cooperative fosters active participation to decision-making processes and, conversely, frequent attendance to general meetings may reinforce the feeling of belonging to the organization.

As regards the other two dependent variables, belonging to Ecopower 1 and to BeauVent has a significantly negative effect on generalized interpersonal trust, while the effect of belonging to Ecopower 2 is significantly positive. This seemingly contradictory result is discussed further in Section 5. As for the presence of other members in social networks, the three coefficients are significantly positive. 


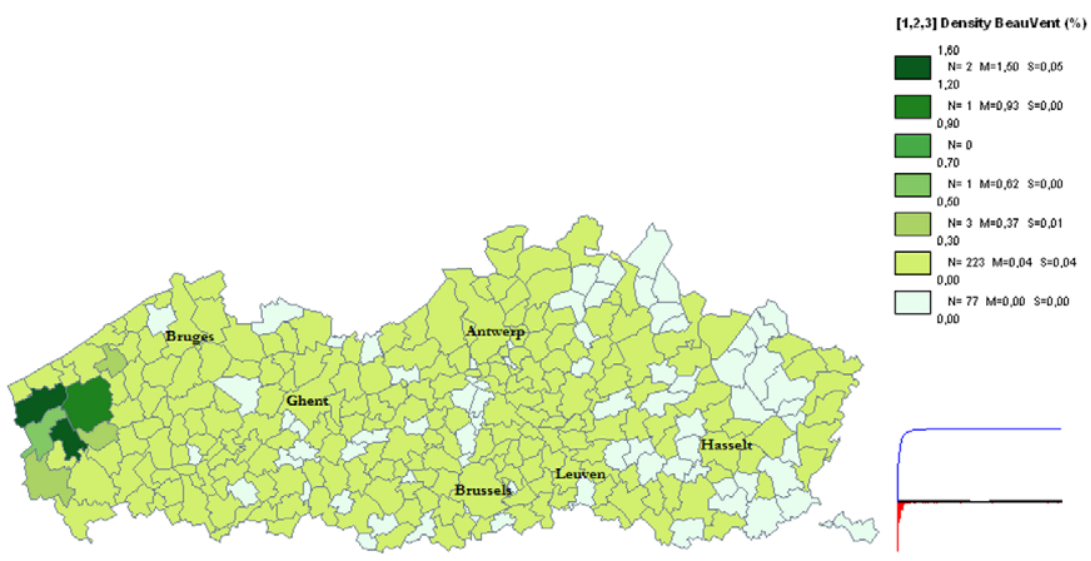

Figure 1 - Spatial density of BeauVent membership in Flanders.

Source: Created by the authors with the Philcarto software on the basis of the data provided by the cooperative.

[Colour figure can be viewed at wileyonlinelibrary.com]
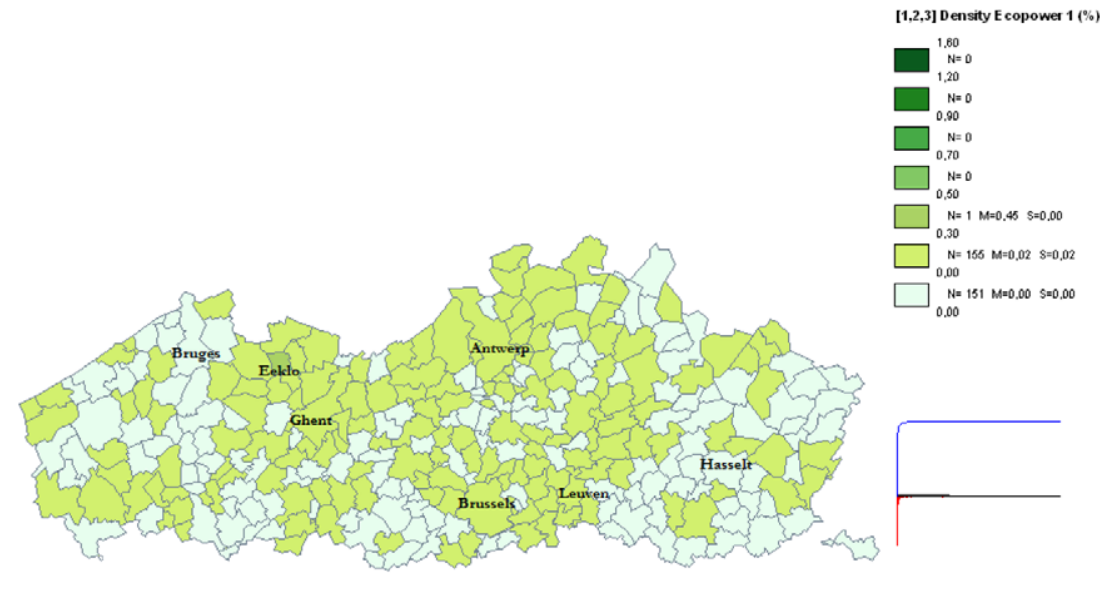

Figure 2 - Spatial density of Ecopower 1 and Ecopower 2 in Flanders.

Source: Created by the authors with the Philcarto software on the basis of the data provided by the cooperative.

[Colour figure can be viewed at wileyonlinelibrary.com]

\subsection{Introducing the spatial dimension of social capital}

In Section 2.3.2., it was argued that the spatial characteristics of the membership may have an influence on the formation of social capital. In this section, spatial factors and their influence on social capital are further explored.

Data provided by the cooperatives enable us to compute the geographical distribution of the whole population of cooperative members at the municipality level. Figures 1, 2 and 3 present the maps of the density of members (computed as the percentage of cooperative members in the total municipality population) in the different Flemish 


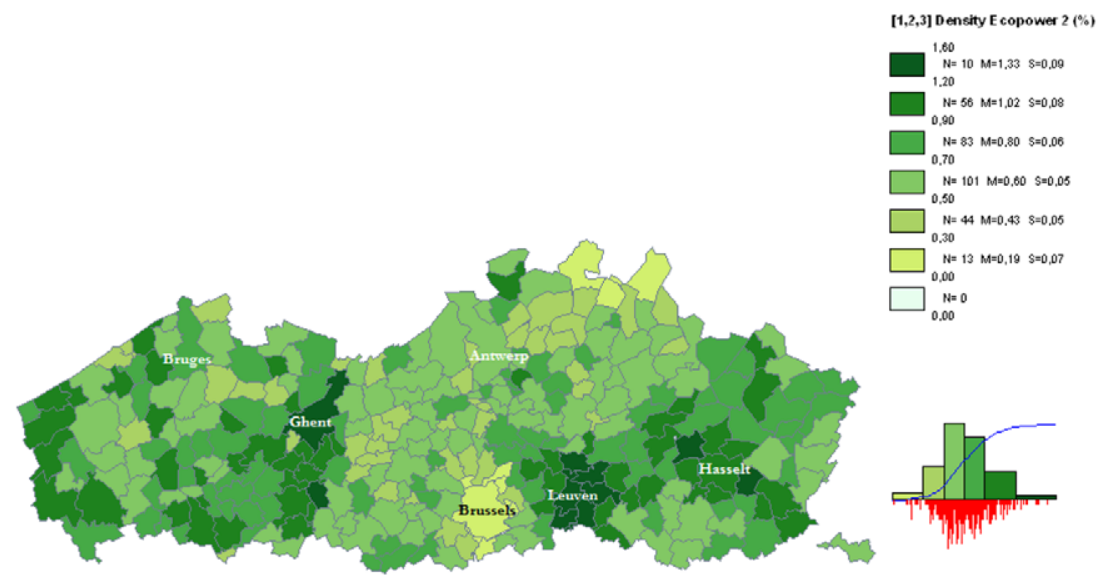

Figure 3 - Spatial density of Ecopower 3 in Flanders.

Source: Created by the authors with the Philcarto software on the basis of the data provided by the cooperative.

[Colour figure can be viewed at wileyonlinelibrary.com]

municipalities for BeauVent, Ecopower 1 and $2,{ }^{12}$ and Ecopower 3 respectively. While the third cohort of Ecopower members (Figure 3 ) is distributed relatively evenly throughout Flanders, with some more densely populated areas in cities such as Ghent and Leuven, BeauVent members (Figure 1) are far more concentrated in the Western part of the region, where the different projects run by the cooperative are located.

Finally, regarding the first two cohorts of Ecopower members (Figure 2), the spatial pattern is less clear, partly because the absolute number of members is much lower than in the other two groups. The only municipality with a density of over 0.30 per cent of members is Eeklo, in East Flanders. This is where the cooperative installed its first wind turbines in 2000 and launched a recruitment campaign to attract new members. Overall, there are appreciable differences in the spatial distribution of the different groups of cooperative members. BeauVent membership is the group for which spatial patterns are the clearest. BeauVent members form a community that is much more based on place as compared to the two cohorts of Ecopower members.

Furthermore, it is interesting to combine these spatial distributions with data about the degree of urbanization of Flemish municipalities, based on the OECD concept of urbanization. ${ }^{13}$ Figure 4 presents a map of urban and rural municipalities in Flanders. As shown on the map, many rural municipalities are located in West Flanders and correspond to those where BeauVent members are more concentrated. In fact, 20 per cent of all BeauVent members live in a rural municipality, as compared to only 2.22 per cent of Ecopower members. This difference is statistically significant $\left(\chi^{2}=2.3 \mathrm{e}+03\right.$,

12 Ecopower 1 and Ecopower 2 have been analyzed together owing to the few observations relating to them.

13 According to the OECD, a municipality is rural if its population density is inferior to 150 inhab. $/ \mathrm{km}^{2}$. 


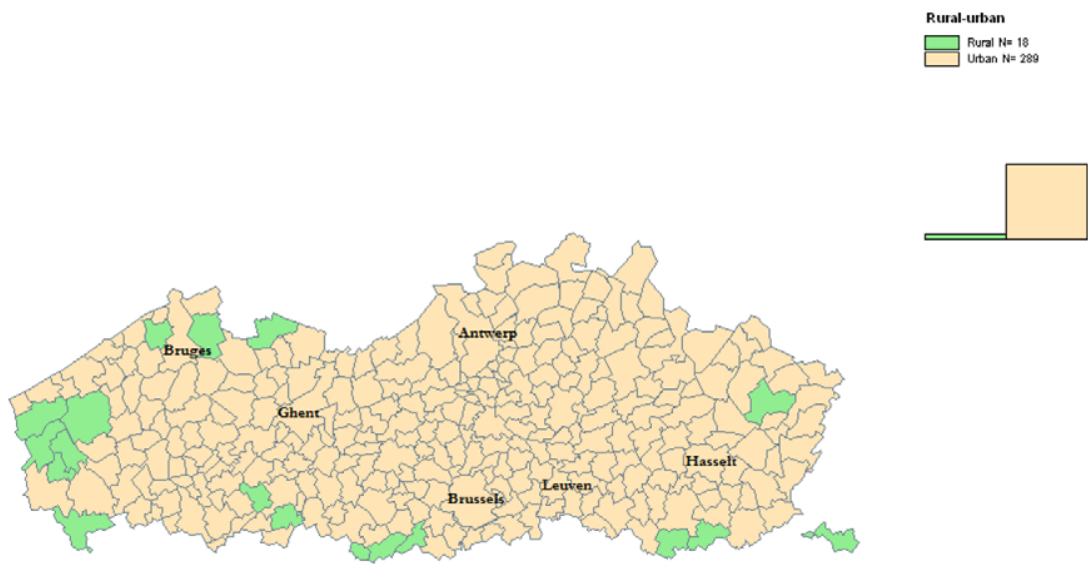

Figure 4 - Urban and rural municipalities in Flanders, 2014.

Source: Created by the authors with the Philcarto software on the basis of the data provided by the cooperatives and Service Public Fédéral Économie (2014).

[Colour figure can be viewed at wileyonlinelibrary.com]

$p=0.000$ ). Thus, the spatial characteristics of Ecopower and BeauVent membership differ in two ways: first, BeauVent members are more spatially concentrated and, second, a higher proportion of them is located in rural areas as compared to Ecopower members. In turn, these additional spatial differences can be expected to have some influence on members' social capital, as suggested in Section 2.3.2.

To account for these spatial patterns in our data, we made several adjustments to the econometric regressions (Table 8). Given that cooperative members are clustered in the 308 municipalities of Flanders, we included fixed effects $\eta_{m}$ for each municipality in the models. In doing so, we control for unobserved heterogeneity at the municipality level. Since cooperative members are clustered both within a group and within a municipality, we have to adjust errors to account for correlation along both dimensions. One way of controlling for clustering in two non nested dimensions is to use two-way cluster-robust standard errors (Cameron et al. 2011). Petersen (2009), however, shows that when there are only a few clusters in one dimension, clustering by the more frequent cluster yields results that are almost identical to clustering by both dimensions. This is confirmed by Thompson (2011) and Cameron et al. (2011), who show that double clustering makes sense only when we have sufficient clusters along both dimensions. In our case, the number of group clusters is very small (3) as compared to the number of municipalities (308). For this reason, we use cluster-robust standard errors for correlation within municipality only.

As regards social identification, the marginal effects of belonging to the first two cohorts of Ecopower members are still significantly positive in both cases, while belonging to BeauVent does not play a significant role. Regarding interpersonal trust and the presence of other members in the social network, the coefficient of ECOPOWER2 is significantly positive; the coefficients of ECOPOWER1 and BEAUVENT, however, are not significant. 
Table 8 - Introducing the spatial dimension of social capital

\begin{tabular}{|c|c|c|c|}
\hline & $\begin{array}{c}\text { Social } \\
\text { identification }\end{array}$ & $\begin{array}{c}\text { Generalized } \\
\text { trust }\end{array}$ & $\begin{array}{l}\text { Members in } \\
\text { social network }\end{array}$ \\
\hline & $\begin{array}{l}\text { Ordered } \\
\text { probit }\end{array}$ & $\begin{array}{l}\text { Ordered } \\
\text { probit }\end{array}$ & Probit \\
\hline ECOPOWER1 & $0.31^{*}(0.17)$ & $-0.13(0.23)$ & $0.11(0.11)$ \\
\hline ECOPOWER2 & $0.37^{* \star \star}(0.13)$ & $0.23^{*}(0.13)$ & $0.16^{\star \star}(0.06)$ \\
\hline BEAUVENT & $-0.02(0.13)$ & $-0.03(0.18)$ & $0.08(0.11)$ \\
\hline EDUCATION & $-0.04(0.03)$ & $0.12^{* * \star}(0.04)$ & $0.02(0.02)$ \\
\hline INCOME & $0.03(0.04)$ & $0.12^{\star \star \star}(0.03)$ & $0.01(0.02)$ \\
\hline GENDER & $0.11^{\star *}(0.05)$ & $-0.07(0.05)$ & $-0.01(0.03)$ \\
\hline AGE & $0.01^{* \star}(0.00)$ & $0.01^{* *}(0.00)$ & $0.00^{*}(0.00)$ \\
\hline DEMOCRATIC & $0.67^{* * \star}(0.06)$ & $0.09(0.05)$ & $0.04(0.02)$ \\
\hline GREEN & $0.50^{* \star \star}(0.05)$ & $0.13^{* *}(0.05)$ & $-0.03(0.03)$ \\
\hline $\mathrm{ROI}$ & $0.03(0.05)$ & $-0.19^{\star \star \star}(0.05)$ & $0.06^{\star *}(0.03)$ \\
\hline PRICE & $0.06(0.04)$ & $-0.05(0.05)$ & $-0.04^{\star \star}(0.02)$ \\
\hline ADVICE & $0.25^{* * \star}(0.05)$ & $0.10(0.06)$ & $0.14^{\star \star \star}(0.02)$ \\
\hline PROENVORIENT & $0.64^{* * *}(0.04)$ & $0.16^{* * \star}(0.05)$ & $0.08^{\star \star \star}(0.02)$ \\
\hline DISTRIBUTIVE & $-0.13^{\star \star}(0.05)$ & $-030^{\star \star \star}(0.05)$ & $-0.01(0.02)$ \\
\hline PROCEDURAL & $0.18^{* * \star}(0.05)$ & $0.49^{\star \star \star}(0.04)$ & $0.02(0.02)$ \\
\hline AGM & $0.56^{* \star *}(0.12)$ & $-0.13(0.14)$ & $0.11^{*}(0.06)$ \\
\hline Fixed effects for professional status & YES & YES & YES \\
\hline Fixed effects for Municipalities & YES & YES & YES \\
\hline$N$ & 2836 & 2837 & 2767 \\
\hline Pseudo- $R^{2}$ & 0.0801 & 0.054 & 0.079 \\
\hline
\end{tabular}

Source: Survey (2014). Note: Cluster-robust standard errors are in parentheses. ${ }^{*} p<.10 ;{ }^{* *} p<.05 ;{ }^{* * *} p<.01$.

\section{Discussion}

The main finding of this paper is that the type and level of social capital clearly differs depending on whether the cooperative is oriented toward mutual or public benefit. Indeed, Ecopower members who joined the organization during the "public benefit' phases and BeauVent members identify more strongly with the cooperative than Ecopower members who joined it during the 'mutual benefit' phase. In addition, belonging to the early cohorts of Ecopower and to BeauVent has positive marginal effects on the probability of having fellow members in one's direct social network. Hence, contrary to what Hatak et al. (2016) argue, mutual benefit does not appear to be associated with a tight-knit, closed network structure. Rather, the results suggest that an orientation toward mutual benefit is correlated with a more open network structure and weaker ties between members.

The results for generalized interpersonal trust are less clear-cut. Having joined Ecopower during its first phase or belonging to BeauVent is negatively associated with generalized trust; on the other hand, having joined Ecopower in its second phase is negatively related with the latter, and leads to contradictory results. Moreover, when controlling for municipality fixed effects, there is no significant difference between the first cohort of Ecopower members or BeauVent members and the third cohort of Ecopower members. This raises the question whether generalized trust is an adequate measure of cooperative members' social capital in the first place. Indeed, in contrast to the other two 


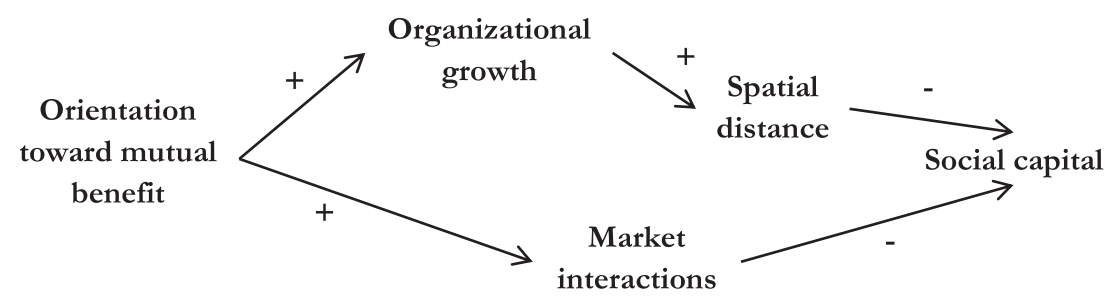

Figure 5 - The relationship between mutual benefit and social capital.

Source: Constructed by authors.

forms of social capital which are directly linked to cooperative membership, generalized trust is a vague and abstract concept which reflects a general propensity to trust others without reference to any specific setting. Furthermore, according to different studies, survey measures related to generalized trust are not necessarily good predictors of actual trusting behavior in experimental trust games (Glaeser et al. 2000; Ostrom and Ahn 2003). Thus, the inconclusive results that we observed may be due to the limitations of measures of generalized trust for capturing the social capital created in cooperatives.

Yet, the identification of significant effects in the case of social identification and network structure does not explain the underlying mechanisms behind the relationship between the orientation toward mutual or public benefit and social capital. Three factors are likely to play a role in explaining this relationship. First, we have seen that spatial factors had an important influence. Indeed, the positive marginal effects of belonging to BeauVent on social identification and the presence of other members in the individual's social network vanish when controlling for municipality fixed effects. This result suggests that the difference between BeauVent members and late Ecopower members is mediated by the distinct spatial patterns of the groups. This result also holds for the first cohort of Ecopower members as regards the presence of other members in one's social network. Second, spatial factors are closely related with organizational growth. Indeed, the process of organizational transition from a public to a mutual benefit orientation that Ecopower went through was accompanied by a sustained expansion of the number of members and of the geographical scope of its activities. However, the effect of belonging to the second cohort of Ecopower is robust to the inclusion of spatial variables. This suggests that spatial factors do not entirely explain the difference between Ecopower 1 and Ecopower 3. An additional explanatory factor may be related to the very nature of mutual benefit. Indeed, in the case of electricity supply, the benefits to members take the form of a market relationship. Now, it was argued in Section 2.2. that market interactions limit the creation of social capital, as they are typically characterized by ephemerality of contact and anonymity among interacting actors. Hence, by attaching benefits in the form of electricity supply to cooperative membership, Ecopower may have modified the incentive structure faced by existing and potential members. Ecopower then started attracting members who were quite distinct from early members and who developed more of a customer attitude in wanting to benefit from the advantages of electricity supply without being strongly involved. This modified the composition of the membership and diluted its social capital. In line with this interpretation, Bauwens (2016) shows that late Ecopower members not only identify less with the cooperative and have weaker linkages with other cooperative members, but are more motivated by the economic 
incentives linked to electricity supply than early Ecopower members. Figure 5 summarizes these relationships.

\section{Conclusion}

Cooperatives may play an important role in transitions toward a sustainable economy through the creation or mobilization of social capital. Yet, the different organizational models in this sector may be associated with distinct types and levels of social capital. This paper sought to assess the differences between mutual and public benefit organizations in terms of the type and level of social capital they contain, focusing on the case of renewable energy cooperatives. Overall, our results indicate that mutual and public benefit organizations are indeed characterized by different types and levels of social capital. An orientation toward public (mutual) benefit is associated with a closed (open) network structure and a stronger (weaker) social identification to the organization.

As in any research project, the choices made in this study reveal some limitations in our findings, which suggest various avenues for future research. First, the relationship between mutual benefit and market interactions highlighted above is fundamentally related to the type of cooperatives analyzed here, namely consumer cooperatives. In other types of cooperatives, mutual benefit may take other forms than a market transaction. For instance, in a worker's cooperative, the relationship that connects the cooperative to its members is typically an employment contract. Thus it would be interesting to look at this relationship in other types of cooperatives as well as other types of social economy organizations.

Second, our data is a cross-sectional snapshot of current members, while the process in which we are interested occurred in the past. This temporal discrepancy may introduce a bias. In particular, as social capital may decrease over time because of organizational growth and the introduction of market incentives, the positive association of public benefit with social capital might be underestimated. Similarly, there may be some overlap between the public and mutual benefit settings. For instance, many members belonging to Ecopower 1, Ecopower 2 and BeauVent are today supplied by Ecopower, although they did not join Ecopower during its supply phase. ${ }^{14}$ However, our statistically significant differences between groups suggest that the distinction between mutual and public benefit does matter, even in the presence of these potential biases. It would be interesting to collect longitudinal data to assess the evolution of social capital over time.

Third, it would be insightful to further explore the relationships between the orientation toward mutual and public benefit, spatial factors and organizational growth. Our paper has highlighted a positive relationship between mutual benefit, strong organizational growth and increasing spatial distance. Again, it would be interesting to know

14 More precisely, 93.0\%, 96.8\%, 95.5\% and 37.3\% of Ecopower 1, Ecopower 2, Ecopower 3 and BeauVent members respectively are supplied by Ecopower. 
whether this relationship holds in other types of cooperatives, in other SE organizations and in other geographical contexts.

In terms of policy and managerial implications, the findings highlight the tradeoff that is likely to arise between the creation and maintenance of a high level of social capital and the scaling up of activities. On the one hand, mutual service provision is a powerful incentive to attract new members and raise financial capital, thereby scaling up positive societal impacts and ensuring financial viability of organizations. On the other hand, the downside is that this mutuality dimension weakens the social capital within organizations, as the case of Ecopower shows. Hence, the findings suggest that managers should compensate the weakening of social bonds between members linked to the orientation toward mutual benefit by ways to reconnect with the social base of economic activities. Alternatively, RE cooperative managers could favor growth paths other than an increase of members and an accumulation of assets in a single organization, e.g. through the replication and franchising of a successful business model or through the free and open flow of knowledge and the sharing of relevant experience. The constitution of inter-organizational networks is another interesting way to respond to the problems of small scale and limited resources and skills (see e.g. Sacchetti and Tortia 2016). By constituting networks, SE organizations are able to attain economies of scale by sharing information, equipment, and skills. Cooperation in the local business networks that constitute 'the third Italy' along with their local governments provides one example of such an inter-organizational network. By creating economies of scale in marketing, research and training, inter-firm cooperation enables small firms in Northern Italy to compete with giant corporations. Hence, developing inter-organizational networks seems to be a prominent way to preserve the benefits of local anchorage of initiatives and simultaneously take advantage of economies of scale and the connections to the wider sustainability agenda at the national and international levels.

\section{REFERENCES}

ADGER W. N., 2003, 'Social capital, collective action, and adaptation to climate change', Economic Geography, 79, 387-404.

ALCHIAN A. A. and DEMSETZ H., 1972, 'Production, information costs, and economic organization', American Economic Review, 62, 777-795.

BAUWENS T., 2010, 'La coopérative Crédal: rencontre de deux mondes', in S. MERTENS (ed.), La Gestion des Entreprises Sociales, Edipro, Liège, pp. 345-351.

BAUWENS T., 2015, 'Propriété coopérative et acceptabilité sociale de l'éolien terrestre', Reflets et Perspectives de la Vie Economique, 1, 59-70.

BAUWENS T., 2016, 'Explaining the diversity of motivations behind community renewable energy', Energy Policy, 93, 278-290.

BAUWENS T., GOTCHEV B. and HOLSTENKAMP L., 2016, 'What drives the development of community energy in Europe? The case of wind power cooperatives', Energy Research and Social Science, 13, 136-147.

BAUWENS T. and LEMAITRE A., 2014, 'Popular economy in Santiago de Chile: State of affairs and challenges', World Development, 64, 65-78. 
BECCHETTI L. and PISANI F., 2015, 'The determinants of outreach performance of social business: an inquiry on Italian social cooperatives', Annals of Public and Cooperative Economics, 86, 105-136.

BEGGS J. J., HAINES, V. A. and HURLBERT J. S., 1996, 'Revisiting the rural-urban contrast: personal networks in nonmetropolitan and metropolitan settings', Rural Sociology, 61, 306-325.

BEN-NER A. and GUI B., 2000, 'The theory of nonprofit organizations revisited', in H. K. ANHEIER and A. BEN-NER (eds.), The Study of the Nonprofit Enterprise: Theories and Approaches, Kluwer Academic/Plenum, New York, pp. 3-26.

BIRCH K. and WHITTAM G., 2008, 'The third sector and the regional development of social capital', Regional Studies, 42, 437-450.

BORZAGA C. and DEFOURNY J., 2001, The Emergence of Social Enterprise, Routledge, London.

BORZAGA C. and SANTUARI A., 2001, 'Italy: from traditional co-operatives to innovative social enterprises', in C. BORZAGA and J. DEFOURNY (eds.), The Emergence of Social Enterprise, Routledge, London, pp. 166-181.

BORZAGA C. and SPEAR R., 2004, Trends and Challenges for Co-operatives and Social Enterprises in Developed and Transition Countries, Edizione 31, Trento.

BOWLES S., 1998, 'Endogenous Preferences: The cultural consequences of markets and other economic institutions', Journal of Economic Literature, 36, 75-111.

BOWLES S. and GINTIS H., 2002, 'Social capital and community governance', Economic Journal, 112, F419-F436.

BREHM J. and RAHN W., 1997, 'Individual-level evidence for the causes and consequences of social capital', American Journal of Political Science, 41, 9991023.

BREWER M. B. and KRAMER R. M., 1986, 'Choice behavior in social dilemmas: Effects of social identity, group size, and decision framing', Journal of Personality and Social Psychology, 50, 543-549.

BROWN-KRUSE J. and HUMMELS D., 1993, 'Gender effects in laboratory public goods contribution', Journal of Economic Behavior and Organization, 22, 255-267.

BRUNIE A., 2009, 'Meaningful distinctions within a concept: Relational, collective, and generalized social capital', Social Science Research, 38, 251-265.

BYRNE N., HEINONEN K. and JUSSILA I., 2015, 'The role of proximity in value preferences: a study of consumer co-operatives', Annals of Public and Cooperative Economics, 86, 339-361.

CAMERON A. C., GELBACH J. B. and MILLER D. L., 2011, 'Robust inference with multiway clustering', Journal of Business and Economic Statistics, 29, 238-249.

CASTRO P., GARRIDO M., REIS E. and MENEZES J., 2009, 'Ambivalence and conservation behaviour: An exploratory study on the recycling of metal cans', Journal of Environmental Psychology, 29, 24-33.

COLEMAN J.S., 1988, 'Social capital in the creation of human capital', American Journal of Sociology, 94, S95-S120. 
COLEMAN J.S., 1990, Foundations of Social Theory, Harvard University Press, Cambridge, MA.

COLQUITT J.A., 2001, 'On the dimensionality of organizational justice: A construct validation of a measure', Journal of Applied Psychology, 86, 386-400.

DAWES R. M., VAN DE KRAGT A. J. C. and ORBELL J. M., 1988, 'Not me or thee but we: The importance of group identity in eliciting cooperation in dilemma situations: Experimental manipulations', Acta Psychologica, 68:1-3, 83-97.

DEFOURNY J., 1995, 'L'avenir des pratiques coopératives dans un monde en mutation', in M.-T. SEGUIN (ed.), Pratiques coopératives et mutations sociales, L'Harmattan, Paris, pp. 13-25.

DEFOURNY J., 2001, 'Introduction: From third sector to social enterprise', in C. BORZAGA and J. DEFOURNY (eds.), The Emergence of Social Enterprise, Routledge, London, pp. 1-28.

DEFOURNY J. and DEVELTERE P., 2000, 'The social economy: the worldwide making of a third sector', in J. DEFOURNY, P. DEVELTERE and B. FONTENEAU (eds.), Social Economy in North and South, HIVA/Centre d'Économie Sociale-ULg, Liège/Leuven, pp. 17-47.

DEGLI ANTONI G. and PORTALE E., 2011, 'The effect of corporate social responsibility on social capital creation in social cooperatives', Nonprofit and Voluntary Sector Quarterly, 40, 566-582.

DELACOLETTE N., CLAUS B., VERBEEK B., SOHET X., WARLOP L. and DARDENNE B., 2011, Fostering Sustainable Behaviors: Community-Based Social Marketing, Belgian Science Policy Final Report, Brussels

FENG L., FRIIS A. and NILSSON J., 2016, 'Social capital among members in grain marketing cooperatives of different sizes', Agribusiness, 32, 113-126.

FICI A., 2009, 'Cooperatives and social enterprises: Comparative and legal profile', in B. ROELANTS (ed.), Cooperatives and Social Enterprises: Governance and Normative Frameworks, CECOP, Brussels.

FICI A., 2013, 'Cooperative identity and the law', European Business Law Review, 24, $37-64$.

FIELDING K. S., MCDONALD R. and LOUIS W. R., 2008, 'Theory of planned behaviour, identity and intentions to engage in environmental activism', Journal of Environmental Psychology, 28, 318-326.

FONTENEAU B., NYSSENS M. and SALAM FALL A., 1999, 'Le secteur informel: creuset de pratiques d'économie solidaire', in J. DEFOURNY, P. DEVELTERE and B. FONTENEAU (eds.), L'économie sociale au Nord et au Sud, De Boeck Université, pp. 159-178.

FUKUYAMA F., 1995, Trust: The Social Values and the Creation of Prosperity, Free Press, New York.

GINTIS H., 2000, 'Strong reciprocity and human sociality', Journal of Theoretical Biology, 206, 169-179.

GLAESER E. L., LAIBSON D. I., SCHEINKMAN J. A. and SOUTTER C. L., 2000, 'Measuring trust', Quarterly Journal of Economics, 115, 811-846. 
GOETTE L., HUFFMAN D. and MEIER S., 2006, 'The impact of group membership on cooperation and norm enforcement: evidence using random assignment to real social groups', American Economic Review, 96, 212-216.

GRANOVETTER M., 1985, 'Economic action and social structure: the problem of embeddedness', American Journal of Sociology, 91, 481-510.

GRANOVETTER M. S., 1973, 'The strength of weak ties', American Journal of Sociology, 78, 1360-1380.

GROSSMAN S. J. and HART O. D., 1986, 'The costs and benefits of ownership: a theory of vertical and lateral integration', Journal of Political Economy, 94, 691-719.

GUI B., 1991, "The economic rationale for the "third sector": nonprofit and other noncapitalist organizations', Annals of Public and Cooperative Economics, 62, 551572.

HANSMANN H., 1996, The Ownership of Enterprise, The Belknap Press of Harvard University Press, Cambridge, MA.

HART O. and MOORE J., 1990, 'Property rights and the nature of the firm', Journal of Political Economy, 98, 1119-1158.

HATAK I., LANG R. and ROESSL D., 2016, 'Trust, social capital, and the coordination of relationships between the members of cooperatives: a comparison between memberfocused cooperatives and third-party-focused cooperatives', Voluntas: International Journal of Voluntary and Nonprofit Organizations, 27, 1218-1241.

HILBE J.M., 2009, Logistic Regression Models, Chapman and Hall/CRC Press, Boca Raton, FL.

HUYBRECHTS B., 2007, 'Fondements et implications de la diversité organisationnelle au sein du commerce équitable', Annals of Public and Cooperative Economics, 78, 195-219.

HUYBRECHTS B. and MERTENS S., 2014, 'The relevance of the cooperative model in the field of renewable energy', Annals of Public and Cooperative Economics, 85, 193-212.

JACQUEMAIN M., 1995, 'Représentations de la justice sociale: l'exemple de la Belgique francophone', L’Année Sociologique, 45, 399-430.

JONES D. C. and KALMI P., 2012, 'Economies of scale versus participation: a cooperative dilemma?', Journal of Entrepreneurial and Organizational Diversity, 1, 3764.

KAWACHI I., KENNEDY B. P., LOCHNER K. and PROTHROW-STITH D., 1997, 'Social capital, income inequality, and mortality', American Journal of Public Health, 87, 1491-1498.

KNACK S. and KEEFER P., 1997, 'Does social capital have an economic payoff? A cross-country investigation', Quarterly Journal of Economics, 112, 1251-1288.

KOTCHEN M. J. and MOORE M. R., 2007, 'Private provision of environmental public goods: Household participation in green-electricity programs', Journal of Environmental Economics and Management, 53, 1-16. 
KRAMER R. M. and BREWER M. B., 1984, 'Effects of group identity on resource use in a simulated commons dilemma', Journal of Personality and Social Psychology, 46, 1044-1057.

LANG R. and ROESSL D., 2011a, 'Contextualizing the governance of community cooperatives: Evidence from Austria and Germany', Voluntas: International Journal of Voluntary and Nonprofit Organizations, 22, 706-730.

LANG R. and ROESSL D., 2011b, 'The role of social capital in the development of community-based co-operatives', in M. TUUNANEN, J. WINDSPERGER, G. CLIQUET and G. HENDRIKSE (eds.), New Developments in the Theory of Networks: Franchising, Alliances and Cooperatives, Physica-Verlag, Heidelberg, pp. 353370.

LITVINE D. and WÜSTENHAGEN R., 2011, 'Helping "light green" consumers walk the talk: Results of a behavioural intervention survey in the Swiss electricity market', Ecological Economics, 70, 462-474.

MANCINO A. and THOMAS, A., 2005, 'An Italian pattern of social enterprise: The social cooperative', Nonprofit Management and Leadership, 15, 357-369.

MORI P.A., 2014, 'Community and cooperation: the evolution of cooperatives towards new models of citizens' democratic participation in public services provision', Annals of Public and Cooperative Economics, 85, 327-352.

NARAYAN D. and CASSIDY M. F., 2001, 'A dimensional approach to measuring social capital: development and validation of a social capital inventory', Current Sociology, 49, 59-102.

NILSSON J., KIHLEN A. and NORELL L., 2009, 'Are traditional cooperatives an endangered species? About shrinking satisfaction, involvement and trust', International Food and Agribusiness Management Review, 12, 1-22.

ONYX J. and BULLEN P., 2000, 'Measuring social capital in five communities', Journal of Applied Behavioral Science, 36, 23-42.

OSTROM E., 1994, 'Constituting social capital and collective action', in R. KEOHANE and E. OSTROM (eds.), Local Commons and Global Interdependence: Heterogeneity and Co-operation in Two Domains, Sage, London.

OSTROM E., 2003, 'Toward a behavioral theory linking trust, reciprocity, and reputation', in E. OSTROM and J. WALKER (eds.), Trust and Reciprocity. Interdisciplinary Lessons from Experimental Research, Russell Sage Foundation, New York, pp. 19-79.

OSTROM E. and AHN T., 2003, Foundations of Social Capital, Edward Elgar, Northampton, MA.

PALDAM M., 2000. 'Social capital: one or many? Definition and measurement', Journal of Economic Surveys, 14, 629-653.

PÉRILLEUX A., HUDON M. and BLOY E., 2011, 'Surplus distribution in microfinance: differences among cooperative, nonprofit, and shareholder forms of ownership', Nonprofit and Voluntary Sector Quarterly, 41, 386-404.

PETERSEN M. A., 2009, 'Estimating standard errors in finance panel data sets: comparing approaches', Review of Financial Studies, 22, 435-480. 
PICCIOTTI A., BERNARDONI A., COSSIGNANI A. and FERRUCCI L., 2014, 'Social cooperatives in Italy: Economic antecedents and regional distribution', Annals of Public and Cooperative Economics, 85, 213-231.

PROUTEAU L. and WOLFF F.-C., 2004, 'Relational goods and associational participation', Annals of Public and Cooperative Economics, 75, 431-463.

PUTNAM R., 1993, Making Democracy Work: Civic Traditions in Modern Italy, Princeton University Press, Princeton, NJ.

ROTHSTEIN B., 2001, 'Social capital in the social democratic welfare state', Politics and Society, 29, 207-241.

ROTHSTEIN B. and EEK D., 2009, 'Political corruption and social trust: an experimental approach', Rationality and Society, 21, 81-112.

RUTTEN R., WESTLUND H. and BOEKEMA F., 2010, 'The spatial dimension of social capital', European Planning Studies, 18, 863-871.

SACCHETTI S. and TORTIA E., 2016, 'The extended governance of cooperative firms: inter-firm coordination and consistency of values', Annals of Public and Cooperative Economics, 87, 93-116.

SERVICE PUBLIC FÉDÉRAL Économie, 2014, 'Typologie des Communes selon 2 concepts différents: OCDE et EUROSTAT[1] - Home'. http://statbel.fgov.be/fr/ statistiques/chiffres/environnement/geo/typologies_communes/.

SEYFANG G. and HAXELTINE A., 2012, 'Growing grassroots innovations: exploring the role of community-based initiatives in governing sustainable energy transitions', Environment and Planning C: Government and Policy, 30, 381-400.

SEYFANG G., PARK J. J. and SMITH A., 2013, 'A thousand flowers blooming? An examination of community energy in the UK', Energy Policy, 61, 977-989.

SEYFANG G. and SMITH A., 2007, 'Grassroots innovations for sustainable development: Towards a new research and policy agenda', Environmental Politics, 16, 584603.

SMITH A., 2012, 'Civil Society in Sustainable Energy Transitions', in G. VERBONG and D. LOORBACH (eds.), Governing the Energy Transition: Reality, Illusion, or Necessity, Routledge, New York.

SOMERVILLE P. and MCELWEE G., 2011, 'Situating community enterprise: A theoretical exploration', Entrepreneurship and Regional Development, 23, 317-330.

SPEAR R., 2000, 'The co-operative advantage', Annals of Public and Cooperative Economics, 71, 507-523.

SPEAR R. and BIDET E., 2005, 'Social enterprise for work integration in 12 European countries: a descriptive analysis', Annals of Public and Cooperative Economics, 76, 195-231.

STÜRMER S. and KAMPMEIER C., 2003, 'Active citizenship: The role of community identification in community volunteerism and local participation', Psychologica Belgica, 43, 103-122.

TAJFEL H., 1978, 'Social categorization, social identity and social comparison', in H. Tajfel (ed.), Differentiation Between Social Groups: Studies in the Social Psychology of Intergroup Relations, Academic Press, London, pp. 61-76. 
THOMPSON S. B., 2011, 'Simple formulas for standard errors that cluster by both firm and time', Journal of Financial Economics, 99, 1-10.

TYLER T. R. and BLADER S. L., 2001, 'Identity and cooperative behavior in groups', Group Processes and Intergroup Relations, 4, 207-226.

VALENTINOV V., 2004, 'Toward a social capital theory of cooperative organization', Journal of Cooperative Studies, 37, 5-20.

WESTLUND H., 1999, 'An interaction-cost pexvrspective on networks and territory', Annals of Regional Science, 33, 93-121.

WHITMARSH L. and O'NEILL S., 2010, 'Green identity, green living? The role of pro-environmental self-identity in determining consistency across diverse proenvironmental behaviours', Journal of Environmental Psychology, 30, 305-314.

WOOLDRIDGE J., 2002, Econometric Analysis of Cross Section and Panel Data. MIT Press, Cambridge, MA. 